\title{
Experience and Inspiration of Foreign Innovation and Entrepreneurship Education
}

\author{
Xiaojun Ma, Chunjiang Li*, Hongwei Pan \\ School of Mechanical Engineering \\ Jiamusi University \\ Jiamusi, Heilongjiang 154007, China \\ *The Corresponding author
}

\begin{abstract}
This paper analyzes the current status of the innovation and entrepreneurship education and its enlightenment of universities and colleges that have opened the education and are from the US, the UK and Japan. It is concluded that domestic universities should learn curriculum system, teaching staff, innovative teaching methods from their foreign counterparts to carry out innovation and entrepreneurship education. Make optimization on the foreign education mode, establish distinct teaching goals and put into practice concretely by taking into consideration of their own objectives and positioning. Build a teaching team that mixes diversified innovation and entrepreneurship education. Moreover, an all-round education support system for innovation and entrepreneurship can be set up with the joint efforts of the government, society, universities and the talent market. Through reform of colleges and universities personnel training mode, improve the school innovation entrepreneurship education system, cultivating students' innovative spirit, pioneering consciousness and innovation ability, and speed up training a number of innovative, entrepreneurial talents that are bold to practice, in a bid to form the good atmosphere where business start-ups and innovation are undertaken by the public. Efforts should be made to improve the quality of personnel training.
\end{abstract}

Keywords-innovation and entrepreneurship education; foreign typical universities and colleges; experience and enlightenment; implementation strategy

\section{INTRODUCTION}

Opinions of the General Office of the State Council for the Implementation of Deepening Education Reform on Innovation and Entrepreneurship in Universities and Colleges (G. B. F. No. [2015]36) calls for deepening the comprehensive reform of national institutions of higher learning, improving the quality of personnel training, promoting high-quality entrepreneurship and employment of college graduates, and accelerating the implementation of the innovation-driven development strategy. Local universities and colleges should fully implement the educational policy of the CPC that moral education is the fundamental task and continue to encourage innovation to lead entrepreneurship and create jobs. Closely centering on the regional economic development and industrial demand at the provincial level, they should take the initiative to adapt to the innovation-driven development strategy, with the theme of promoting quality-oriented education, the core of improving

Funded Project: Key Entrustment Project of Higher Education Teaching Reform Research in Heilongjiang Province (SJGZ20180063) the quality of personnel training, the focus on innovative personnel training mechanism, and the guarantee of improving conditions, policies and measures, and promote the close integration of higher education with science, technology, the economy and society, and strive to train a contingent of innovative and entrepreneurial talents with an innovative spirit and the courage to put themselves into practice, providing strong intellectual support in realizing the connection with local economic development as well as industrial upgrading.

This thesis, taking the representative universities of such typical foreign countries as the United States, Britain and Japan, as the research objects, intends to extract and learning the value implication from multi-link innovation and entrepreneurship education models, including objective system, curriculum system, teaching staff, education method and system, evaluation system and quality assurance system, to help and inspire the development of domestic innovation and entrepreneurship education. Through research and data analysis and combining with current situation of innovation and entrepreneurship education of China, three typical universities and colleges from the US, UK and Japan, namely, Babson College, Said Business School and Kochi University of Technology, are picked up as the sample for analyzing and building innovation and entrepreneurship education model with Chinese characteristics, which is student-centered and processoriented, strengthening ideological and political education guidance and educational innovation, exploring innovation and entrepreneurship drivers from multiple dimensions including system, resources, society and market and improving students' awareness of innovation, innovative thinking, innovation and entrepreneurship, as well as the quality of talent training and employment.

\section{The CURRENT SitUATION OF FOREIGN TyPICAL UNIVERSITIES AND COLLEGES FOR ENTREPRENEURSHIP EDUCATION}

In 1919, Babson College was founded in the United States. In order to adapt to the development strategy of globalization, Babson College opened entrepreneurship education courses in the 1960s to cultivate business giants with an international perspective and elites of social wealth creation. With the continuous development of entrepreneurship education, the college formed a strong entrepreneurial atmosphere and set up 
an entrepreneurship research center in the 1980s, gathering global entrepreneurship talents. Integrated entrepreneurship awareness into the whole process of talent cultivation, it attaches great importance to combining theory with practice, integrating entrepreneurship education with market commercialization, constantly enhancing entrepreneurship education resources such as laboratories and entrepreneurship bases and improving teaching methods and extracurricular teaching activities as well as the quality of entrepreneurship education.

In 1996, Said Business School was founded by Oxford University, aiming to cultivate business leaders and entrepreneurs with an international perspective. Relying on the heritage of Oxford University and inheriting Oxford's international development path, the school aims at the world's leading edge and rigorous academic philosophy, and stand out in the development of entrepreneurship education in Europe. The school attaches great importance to the construction of entrepreneurship education base and the study of business rules. Students, teachers and educational institutions all over the world participate in the school. It also pays attention to the cultivation of business core competence and pushes entrepreneurship education to a higher level and a larger scope through large-scale business entrepreneurship activities. Under the guidance of a modern university system and university governance structure, the school has become the most influential platform for entrepreneurship education in the world.

In 1997, Japan established Kochi University of Technology, as a pioneer of the deepening reform of the university system in Japan. The University continues to optimize the university system and governance structure and the curriculum system of talent training, add entrepreneurial engineering disciplines, carry out interdisciplinary integration of disciplines, and offer courses for entrepreneurs. Under the guidance of the high-tech atmosphere in Japan, the school aims to cultivate diversified pioneering talents, high-tech entrepreneurship and management talents and inter-disciplinary talents urgently needed by the society. The part-time teachers of entrepreneurship education come from excellent leaders of enterprises all over the world. For students who participate in entrepreneurship education, the school gives priority to providing jobs and employment opportunities for well-known enterprises in Japan, including domestic famous Tokyo Stock Exchange, Osaka Stock Exchange and other outstanding enterprises. Some of the students founded companies with global influence, such as CORE, Mo Laser Company and so on.

Babson College in the United States focuses on entrepreneurship education led by ideological entrepreneurship. Through disciplines, academic frontiers, entrepreneurship practice training, second class and other innovative entrepreneurial activities, students' awareness, spirit and ability of innovation and entrepreneurship are gradually cultivated from the shallow to the deep. Said Business School in the United Kingdom implements MQA entrepreneurship education with a period of one year, which aims to cultivate students' innovation and entrepreneurship ability in a short term, advocate return on investment, and create business elites and excellent entrepreneurs. Aiming at closely combining the needs of science and technology and giving full play to the maximum creativity of talents, Kochi University of Technology in Japan has realized the close combination between technical logic and market logic, Integration of universities and society, and cultivate and maximize the benefits of senior talents for economic and social development.

\section{EXPERIENCE FROM FOREIGN TYPICAL UNIVERSITIES AND COLLEGES FOR ENTREPRENEURSHIP EDUCATION}

The course system of innovation and entrepreneurship education of Babson College consists of two modules: undergraduate and MBA. Undergraduate innovation and entrepreneurship education courses can be divided into elementary, intermediate and advanced levels and MBA courses can be divided into basic, professional and supporting courses. The curriculum of innovation and entrepreneurship education has highlighted its coverage and universality, and has integrated humanities and social science, comprehensive quality, history and culture with the curriculum of innovation and entrepreneurship education, so as to realize the gradual innovation and entrepreneurship education curriculum system. The innovation and entrepreneurship education course of Said Business School featured by its highlighting of the proportion of practical education, deep integration of innovation and entrepreneurship projects with course teaching, vigorous cultivation of business entrepreneurship base, the potential of business leaders and outstanding entrepreneurs of students, and the focus on the high rate of return with short project cycle. Kochi University of Technology in Japan strengthens the concept of engineering education and sets up engineering entrepreneurship education courses throughout the whole process of talent training, to achieve close connection between engineering technology and society, and cultivate entrepreneurship and craftsman spirit.

The teaching staff, educational methods and system, evaluation system, quality assurance system and other aspects of Babson College, Said Business School and Kochi University of Technology have high similarity. The teaching staff is composed of full-time and off-campus outstanding entrepreneurs, business elites and senior engineering and technical personnel. Educational methods and systems are integrated with the world's cutting-edge science and technology, academic research and innovation and entrepreneurship education, such as practice and training replace traditional classroom teaching. The evaluation system is implemented by the third party to maximize the coupling and linkage role of government, market and society.

Innovation and entrepreneurship education in domestic universities should fully absorb and optimize typical innovation and entrepreneurship modes in foreign countries from the aspects of curriculum system, teaching staff and innovative teaching methods, and formulate different systems of innovation and entrepreneurship education objectives based on the objective and positioning of each school and implement them concretely, and then set up a mixed team of teachers for innovation and entrepreneurship education, and an all-round education support system for innovation and entrepreneurship that is coupled with the government, society, universities and the market 


\section{THE INSPIRATION OF FOREIGN ENTREPRENEURSHIP EDUCATION MODEL ON THE INNOVATION AND ENTREPRENEURSHIP EDUCATION IN CHINA}

Domestic colleges and universities should strengthen college students' innovation ability, and improve their comprehensive quality. The school should help students to cultivate pioneering consciousness, change the concept of employment, build up their confidence in the business, master entrepreneurial skills, improve the level of entrepreneurship, build the "trinity" of education system of professional education, quality education, innovative entrepreneurship education, and constantly improve the quality of personnel training. First, define the function positioning of innovation and entrepreneurship education. The school should highlight the role of personnel training as the main channel, and establish a personnel training system that integrates professional education, quality education, and innovation and entrepreneurship education. In the teaching process, the school should attach great importance to the goal of talent cultivation, and pay attention to the cultivation of students' innovative spirit, entrepreneurial consciousness and innovative and entrepreneurial ability, promoting the close combination of talent cultivation and entrepreneurial and employment needs. Secondly, reform educational and assessment methods. The school should, based on the nature of curriculum, implement inquiry, heuristic, case, participation and project teaching methods to arouse the students' innovation consciousness, independent thinking and introduce a batch of innovative entrepreneurship education quality online open courses to realize the resource sharing, reform the examination assessment content and ways, and flexible use of the inspection way. The school should also pay attention to process evaluation, the students' innovation, practice and experience. Thirdly, strengthen the development of the curriculum system. The school should carry out general education of innovation and entrepreneurship for all students, and integrate the teaching contents of college students' innovation and entrepreneurship policies, regulations and macro-economy into the teaching of "Foundation of Entrepreneurship". The school should carry out practical training as required by the students with innovative entrepreneurial intention and provide incubation environment and safeguard measures for them. The school should strengthen the innovation and entrepreneurship education in the practice teaching link, making the innovation and entrepreneurship education run through the whole process of talent cultivation, and form the innovation and entrepreneurship education curriculum system that integrates theory and practice, and then integrates policy and entrepreneurship, and effectively improve the quality of talent cultivation. Fourthly, optimize the structure of the teaching staff. In accordance with the principle of focusing on full-time work and combining full-time work with part-time work, the school should establish a part-time tutor pool for innovation and entrepreneurship education through "combination within and outside the school", and encourage professional teachers to integrate their innovative spirit and entrepreneurial awareness into the classroom, supporting the teachers to translate innovation-based scientific and technological achievements into entrepreneurship projects.
Fifthly, strengthen innovation and entrepreneurship practices and training. The school should support the establishment of innovation and entrepreneurship association, entrepreneurship club, innovation and entrepreneurship salon, maker space, and encourage students to hold innovation and entrepreneurship lectures BBS and other forms of activities, giving full play to the leading role of college students' innovation and entrepreneurship training programs, and actively guiding and encouraging students to participate in innovation and entrepreneurship activities. Sixthly, accelerate the establishment of a platform system for entrepreneurial practice. The school should speed up the construction of "Internet +" entrepreneurship network platform, college students' employment, entrepreneurship and innovation service center, and university science and technology parks. Seventhly, promote reform of the system for managing credits and student status. The school should implement the flexible school system, relaxing the length of study of students, and allowing the adjustment of the academic process. After the school evaluation, the students can retain the school roll to suspend business. The school should also establish the credit accumulation and conversion system for innovation and entrepreneurship, and identify students' participation in project research and project research as practical course credits. Eighthly, improve the system of financial support and service guarantee. The school should set up an innovation and entrepreneurship project fund, which can be used to encourage college students or entrepreneurial teams to achieve start-up results, and accelerate the transformation of scientific and technological achievements, serving for college students' innovation and entrepreneurship education.

\section{REFERENCES}

[1] Ma Xiaojun, Li Chunjiang, Zhang Ze. The Development Status and Enlightenment of Innovation and Entrepreneurship Education for Engineering College Students $[\mathrm{J}]$. Pioneering with Science \& Technology Monthly, 2017, 30(13):57-58. (2017-08-18).

[2] Ma Xiaojun, Li Chunjiang, Zhang Ze. Implementation Strategy of Practical Ability Training for Engineering College Students [J]. China Economist, 2017, (07):221-222. (2017-08-18)

[3] Ma Xiaojun, Li Chunjiang, Zhang Ze. Construction of "Five-in-One" Innovation and Entrepreneurship Mode in Local Comprehensive Universities [J]. China Economist, 2017, (06):206-207. (2017-08-18).

[4] Ma Xiaojun, Li Chunjiang, Pan Hongwei. A Study on the Cultivation Mode of Innovative Ability of Engineering Undergraduates in Local Comprehensive Universities[J]. Pioneering with Science \& Technology Monthly, 2017, 30(10):24-26. (2017-08-18)

[5] Ma Xiaojun, Li Chunjiang, Zhang Ze. Construction of the Curriculum System of Entrepreneurial Innovation and Entrepreneurship Education in Local Comprehensive Universities: Take Jiamusi University as an Example[J]. Pioneering with Science \& Technology Monthly, 2017, 30(09):74-76. (2017-08-18)

[6] Shao Defu, Li Chunjiang, Ma Xiaojun. Research on New Engineering Talent Innovation Entrepreneurship Training Mode of Local University[J]. Pioneering with Science \& Technology Monthly, 2017, 30(19):62-64.

[7] Huang Aizhen. The Comparison and Enlightenment of Entrepreneurship Education Mode among the United States, Britain and Japan[D]. Jiangxi University of Finance and Economics, 2012 